This Accepted Author Manuscript is copyrighted and published by Elsevier. It is posted here by agreement between Elsevier and University of Brasilia. Changes resulting from the publishing process - such as editing, corrections, structural formatting, and other quality control mechanisms - may not be reflected in this version of the text. The definitive version of the text was subsequently published in [Tissue and Cell, Volume 34, Issue 3, June 2002, Pages 135-142, doi:10.1016/S0040-8166(02)00021-6].You may download, copy and otherwise use the AAM for non-commercial purposes provided that your license is limited by the following restrictions:

(1) You may use this AAM for non-commercial purposes only under the terms of the CC-BY-NCND license.

(2) The integrity of the work and identification of the author, copyright owner, and publisher must be preserved in any copy.

(3) You must attribute this AAM in the following format: [agreed attribution language, including link to CC BY-NC-ND license + Digital Object Identifier link to the published journal article on Elsevier's ScienceDirect ${ }^{\circledR}$ platform].

Este Manuscrito do Autor Aceito para Publicação (AAM) é protegido por direitos autorais e publicado pela Elsevier. Ele esta disponível neste Repositório, por acordo entre a Elsevier e a Universidade de Brasília. As alterações decorrentes do processo de publicação - como a edição, correção, formatação estrutural, e outros mecanismos de controle de qualidade - não estão refletidas nesta versão do texto. A versão definitiva do texto foi posteriormente publicado em [Tissue and Cell, Volume 34, Número 3, Junho de 2002, Páginas 135-142, doi:10.1016/S00408166(02)00021-6]. Você pode baixar, copiar e utilizar de outra forma o AAM para fins não comerciais , desde que sua licença seja limitada pelas seguintes restrições:

(1) Você pode usar este AAM para fins não comerciais apenas sob os termos da licença CC- BYNC-ND.

(2) A integridade do trabalho e identificação do autor, detentor dos direitos autorais e editor deve ser preservado em qualquer cópia.

(3) Tem de atribuir este AAM no seguinte formato: [acordo na linguagem atribuída, incluindo o link para CC BY-NC-ND licença Digital + DOI do artigo publicado na revista Elsevier ScienceDirect ${ }^{\circledR}$ da plataforma]. 


\title{
A comparative ultrastructural study of spermatozoa of the teiid lizards Cnemidophorus gularis gularis, Cnemidophorus ocellifer, and Kentropyx altamazonica (Reptilia, Squamata, Teiidae)
}

\author{
R.D Teixeira \\ D.M Scheltinga \\ S.E Trauth \\ G.R Colli
}

S.N Báo

\begin{abstract}
The ultrastructure of the spermatozoa of Cnemidophorus gularis gularis, Cnemidophorus ocellifer, and Kentropyx altamazonica is described for the first time. Mature spermatozoa of Cnemidophorus spp. and K. altamazonica differ in the occurrence of a perforatorial base plate, the enlargement of axonemal fibers 3 and 8 , and shape of mitochondria. The comparisons of the ultrastructure sperm of Cnemidophorus spp. and K.altamazonica with Ameivaameiva [J. Morphol. (2002) in press] suggest that Ameiva and Cnemidophorus are more similar to each other than either is to Kentropyx. Statistical analyses reveal that sperm of all three species studied are significantly different in the following dimensions: head, acrosome, distal centriole length, and nuclear shoulders width. There was no variable statistically different between the Cnemidophorus spp. only. The length of the tail, midpiece, entire sperm, and nuclear rostrum are significantly different between $\mathrm{K}$. altamazonica and Cnemidophorus spp. Our results indicate that sperm ultrastructure presents intra and intergeneric variability.
\end{abstract}

Keywords: Cnemidophorus; Kentropyx; lizards; spermatozoa; Teiidae; ultrastructure

\section{Introduction}

Although several studies have attempted to clarify the phylogenetic relationships of teiid genera (Vanzolini \& Valencia, 1965, Presch, 1974 and Rieppel, 1980), additional studies are necessary to develop a comprehensive phylogenetic hypothesis for the family. Several detailed studies have revealed that sperm character data sets contain significant phylogenetic information which can be used in phylogenetic analyses (Jamieson, 1995 and Jamieson, 1999; Teixeira et al., 1999a and Teixeira et al., 1999b). However, high levels of polymorphism in sperm characters of the teiids Cnemidophorus sexlineatus (Newton \& Trauth, 1992) and Ameiva ameiva (Giugliano et al., 2002), and within the teiid genus Tupinambis ( TavaresBastos et al., 2002) have recently been revealed. Thus, intrafamilial variability might be higher than currently thought. Although variability in sperm characters may be a problem in phylogenetic reconstruction, their exclusion from analyses may lead to reduced accuracy ( Wiens, 1995). Hence, additional studies on sperm ultrastructure of teiid genera are essential to 
clarify the level of variability within the family and to assist in the resolution of phylogenetic relationships of teiids.

The Texas spotted whiptail, Cnemidophorus gularis gularis, is a moderately sized lizard and is one of 22 or so bisexual members of the C. sexlineatus species group (Wright, 1993). It ranges from southern Oklahoma to northern Mexico and from eastern Texas to southeastern New Mexico and southwestern Texas. Seven subspecies have been recognized, but the actual number remains in dispute (Degenhardt et al., 1996). Cnemidophorus ocellifer has a wide distribution in South America, ranging from northeastern and central Brazil to northern Argentina ( Vanzolini et al., 1980, Peters \& Orejas-Miranda, 1986 and Colli et al., 1998). Several studies have suggested that C. ocellifer is actually a complex of species ( Rocha et al., 1997 and Rocha et al., 2000). Kentropyx altamazonica is a South American lizard which occurs in open areas of Amazonia, Brazil ( Avila-Pires, 1995). The genus Kentropyx is a well-defined taxonomic group, being the only teiid genus to possess phyloid keeled scutes ( Magnusson \& Lima, 1984 and Gallagher et al., 1986).

The mature spermatozoa of the teiids C. sexlineatus ( Newton \& Trauth, 1992), A. ameiva (Giugliano et al., 2002), and four species of Tupinambis (T. duseni, T. merianae, T. quadrilineatus, and T. teguixin) ( Tavares-Bastos et al., 2002) have been previously examined. We here provide, for the first time, a detailed description of the mature spermatozoa of $C$. gularis gularis, C. ocellifer, and K. altamazonica. Further, we perform statistical analyses of sperm dimensions of the three species, to determine the presence of any significant difference and to ascertain the degree of intrafamilial and intergeneric variability.

\section{Material and methods}

\section{Spermatozoal ultrastructure}

Mature spermatozoa were obtained from adult specimens of C. gularis gularis (Arkansas State University Museum of Zoology, ASUMZ 19019, 18959) collected at Llano County and Somervell County, TX, USA, C. ocellifer (Coleção Herpetológica da Universidade de Brasília, CHUNB 16943, 16944) collected at Pirinópolis, Goiás State, Brazil, and K. altamazonica (CHUNB 5777, 5784) collected at Vilhena, Rondônia State, Brazil.

Two specimens of $C$. gularis gularis were killed by an injection of sodium pentabarbitol within $72 \mathrm{~h}$ of capture. Histotechnical procedures as discussed by Newton and Trauth (1992) were employed to prepare gonads and sperm ducts for transmission electron microscopy 
(TEM). Testes and epididymides were placed into separate vials containing $2 \%$ glutaraldehyde in $0.2 \mathrm{M}$ sodium cacodylate buffer $(\mathrm{pH} 7.2)$. Following fixation for $2 \mathrm{~h}$ in this solution, the material was rinsed in four changes of $0.1 \mathrm{M}$ cacodylate buffer; postfixed in similarly buffered $1 \%$ osmium tetroxide; rinsed in buffer; dehydrated through an ascending series of ethanol/acetone mixtures; infiltrated overnight in a dilute acetone/epoxy resin mixture, and embedded in Mollenhauer's Epon-Araldite mixture number 2. The embedded tissues were then transported to Brisbane, Australia for sectioning and TEM.

Specimens of C. ocellifer and K. altamazonica were killed by an injection of Tiopental ${ }^{\circledR}$. Epididymides were removed and placed in a Petri dish with phosphate-buffered saline (PBS), $\mathrm{pH}$ 7.2, and cut into small pieces. Epididymal tissues were then fixed in a solution containing $2.5 \%$ glutaraldehyde, $2 \%$ paraformaldehyde, and $3 \%$ sucrose in $0.1 \mathrm{M}$ sodium cacodylate buffer, $\mathrm{pH} 7.2$, at $4{ }^{\circ} \mathrm{C}$ overnight. Tissue samples were then rinsed in $0.1 \mathrm{M}$ phosphate buffer, $\mathrm{pH}$ 7.2, postfixed for $80 \mathrm{~min}$ in similarly buffered $1 \%$ osmium tetroxide; rinsed in buffer; dehydrated through series of ascending acetone series (30-100\%) and embedded in Spurr's epoxy resin. Ultrathin sections were stained for $30 \mathrm{~s}$ in Reynold's lead citrate, rinsed in distilled water, then in $6 \%$ aqueous uranyl acetate for $4 \mathrm{~min}$, rinsed in distilled water, and stained for a further $2 \mathrm{~min}$ in lead citrate before final rinsing. Electron micrographs were taken on a Hitachi 300 transmission electron microscope at $75 \mathrm{kV}$.

Light microscopic observations and photographs of glutaraldehyde-paraformaldehyde fixed smears of C. ocellifer and K. altamazonica spermatozoa were made under Nomarski interference contrast using an Olympus $\mathrm{BH} 2$ microscope and an attached OM-2 camera. Measurements of C. gularis gularis spermatozoa were taken from scanning electron micrographs, tissues processed for scanning electron microscopy (SEM) as per Newton and Trauth (1992).

\section{Statistical analyses}

The following dimensions were measured from micrographs of each species: head length, tail length, entire sperm length, midpiece length, acrosome length, nucleus base width, nuclear rostrum length, distal centriole length, epinuclear lucent zone length and width, nuclear shoulder width, ratio principal piece diameter just posterior to annulus to midpiece diameter just anterior to annulus, and ratio principal piece diameter to fibrous sheath diameter just posterior to annulus. Since the assumption of normality was not met, original variables were ranked prior to analyses. To test the null hypothesis of no difference in sperm dimensions among the three species, a separate analysis of variance (ANOVA) was performed 
for each variable. This univariate approach was adopted because complete sets of measurements could not be obtained from individual cells. To avoid the inflation of Type I error, the Bonferroni procedure was adopted: the significance level of $5 \%$ was divided by the number of tests (13), resulting in a significance level of $0.3 \%$ (Zar, 1998). The Tukey test was used to test for pairwise differences among means. Statistical analyses were conducted with SAS v. 8.0 and Systat v. 9.0 for Windows. Throughout the text, means are given \pm 1 SD.

\section{Results}

\section{Spermatozoal ultrastructure}

The spermatozoa of K. altamazonica ( Fig. 3), C. gularis gularis, and C. ocellifer ( Fig. 2) are filiform, consisting of a head region containing acrosomal structures and the nucleus, a midpiece, and a tail region subdivided into principal piece and endpiece ( Fig. $2 Q$ \& R). The spermatozoa of all three species are sufficiently similar to be described together with any differences noted. The spermatozoon of K. altamazonica is depicted diagrammatically in Figure 1. Dimensions of the sperm are provided in Table 1.

Table 1

Sperm dimensions in Cnemidophorus gularis gularis, Cnemidophorus ocellifer, and Kentropyx altamazonica

\begin{tabular}{|c|c|c|c|c|c|}
\hline Characters & Cnemidophorus gularis gularis & Cnemidophorus acellifer & Kentropyx altamazonica & $F$ & $P$ \\
\hline HL & $10.83 \pm 0.29(n=3) \mathrm{a}$ & $13.30 \pm 0.61(n=14) \mathrm{b}$ & $14.71 \pm 0.45(n=13) \mathrm{c}$ & 53.56 & $<0.001^{\circ}$ \\
\hline TL & $40.25 \pm 0.35(n=2) \mathrm{a}$ & $40.13 \pm 2.82(n=7) \mathrm{a}$ & $53.64 \pm 2.81(n=8) b$ & 22.40 & $<0.001^{*}$ \\
\hline ESL & $54.50 \pm 0.00(n=2) \mathrm{a}$ & $56.42 \pm 2.09(n=11) \mathrm{a}$ & $75.58 \pm 2.49(n=10) b$ & 33.90 & $<0.001^{*}$ \\
\hline MPL & $3.48 \pm 0.27(n=5) \mathrm{a}$ & $3.35 \pm 0.32(n=9) \mathrm{a}$ & $7.55 \pm 0.35(n=8) b$ & 24.00 & $<0.001^{*}$ \\
\hline AL & $3.96 \pm 0.11(n=8) a$ & $3.08 \pm 0.14(n=6) b$ & $3.44 \pm 0.22(n=8) c$ & 15.05 & $0.0001^{*}$ \\
\hline NBW & $0.68 \pm 0.04(n=5) \mathrm{a}$ & $0.53 \pm 0.03(n=3) \mathrm{a}$ & $0.64 \pm 0.03(n=3) \mathrm{a}$ & 9.18 & 0.0085 \\
\hline NRL. & $0.77 \pm 0.03(n=5) \mathrm{a}$ & $0.71 \pm 0.05(n=10) \mathrm{a}$ & $0.62 \pm 0.05(n=10) \mathrm{b}$ & 20.21 & $<0.0001^{\circ}$ \\
\hline DCL & $0.92 \pm 0.11(n=6) \mathrm{a}$ & $0.72 \pm 0.07(n=7) \mathrm{b}$ & $0.65 \pm 0.03(n=7) \mathrm{c}$ & 24.40 & $<0.0001^{\bullet}$ \\
\hline ETL & $3.96 \pm 0.11(n=5) \mathrm{a}$ & $3.08 \pm 0.14(n=6) \mathrm{a}$ & $3.44 \pm 0.22(n=7) \mathrm{a}$ & 3.89 & 0.04 \\
\hline ETW & $0.05 \pm 0.01(n=4) a$ & $0.04 \pm 0.00(n=5) \mathrm{a}$ & $0.04 \pm 0.01(n=7) a$ & 0.68 & 0.52 \\
\hline NSW & $0.5 \pm 0.02(n=5) \mathrm{a}$ & $0.37 \pm 0.02(n=4) b$ & $0.42 \pm 0.03(n=5) \mathrm{c}$ & 35.44 & $<0.0001^{\circ}$ \\
\hline $\mathrm{RD}$ & $1.00 \pm 0.00(n=3) \mathrm{a}$ & $0.96 \pm 0.04(n=3) \mathrm{a}$ & $0.95 \pm 0.01(n=2) \mathrm{a}$ & 2.79 & 0.15 \\
\hline $\mathrm{RC}$ & $1.78 \pm 0.24(n=3) \mathrm{a}$ & $1.89 \pm 0.22(n=3) \mathrm{a}$ & $1.96 \pm 0.06(n=2) \mathrm{a}$ & 0.44 & 0.66 \\
\hline
\end{tabular}

Values in micrometers and represented by means \pm 1 SD. F values are for ANOVA. Asterisk $(*)$ indicates means of sperm characters are significantly different at the $0.3 \%$ level, using the Bonferroni method. Different letters represent significant differences at the $5 \%$ level using the Tukey multiple comparisons test. HL: head length, TL: tail length, ESL: entire sperm length, MPL: midpiece length, AL: acrosome length, NBW: nucleus base width, NRL: nuclear rostrum length, DCL: distal centriole length, ETL: epinuclear lucent zone length, ETW: epinuclear lucent zone width, NSW: nuclear shoulders width, RD: ratio diameter of the principal piece diameter to midpiece diameter, and RC: ratio cytoplasm between fibrous sheath to principal diameter. 


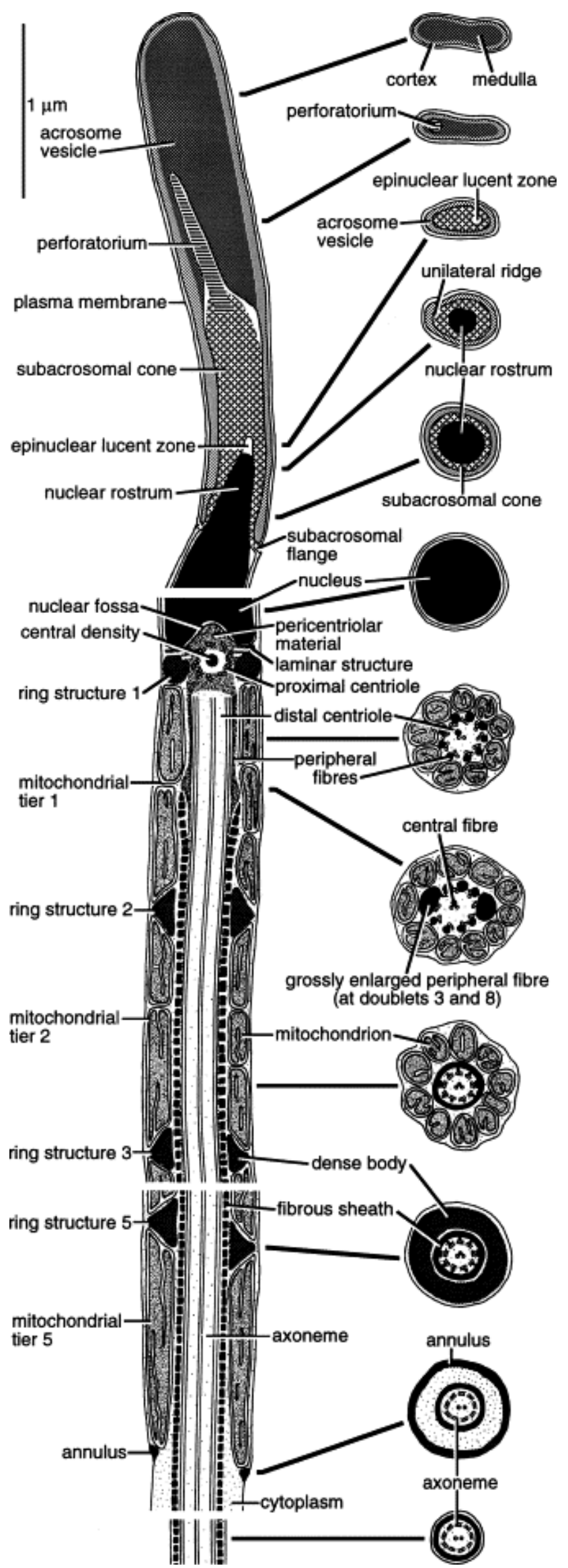

Fig. 1. Kentropyx altamazonica. Drawing of a spermatozoon, in longitudinal and corresponding transverse sections. Drawn from several TEM micrographs. 


\section{Acrosome complex}

The acrosome complex is long and flattened apically and consists of two caps: an external cap, the acrosome vesicle, and an internal cap, the subacrosomal cone (Fig. 2 and Fig. 3). In cross-section, the acrosome vesicle is depressed apically (Fig. 2 and Fig. 3), becoming circular at its base (Fig. 2D-F). Within approximately the basal one third of the acrosome, the acrosome surface presents a lateral ridge, formed by a longitudinal protuberance of the acrosome vesicle (Fig. 2E). The acrosome vesicle caps the subacrosomal cone and is uniformly divided into a narrow cortex and a wide medulla at its anterior portion (Fig. 2 and Fig. 3). In transverse (Fig. 2 and Fig. 3) and longitudinal sections (Fig. 2 and Fig. 3), the cortex exhibits a tubular organization. The medulla appears as a moderately electron-dense structure, filling the interior of the acrosome vesicle. The subacrosomal cone surrounds the tapered anterior end of the nucleus and exhibits a paracrystalline structure (Fig. 2E \& F). The single perforatorium extends from the anterior region of the subacrosomal cone into the acrosome vesicle and ends with a rounded tip (Fig. 2 and Fig. 3). Apically, the perforatorium is not axial and in crosssection can be observed to occur outside the central one third of the flattened acrosome (Fig. 2 and Fig. 3). The two species of Cnemidophorus posses a stopper-like perforatorial base plate, embedded in the apex of the subacrosomal cone ( Fig. 2A). In K. altamazonica, there is a slight densification between the base of the perforatorium and the anterior extremity of the subacrosomal cone. However, we do not consider this feature to be a perforatorial base plate. Within the anterior limit of the subacrosomal cone, anterior to the condensed chromatin of the nuclear rostrum, an epinuclear electron lucent zone is present ( Fig. 2 and Fig. 3). 


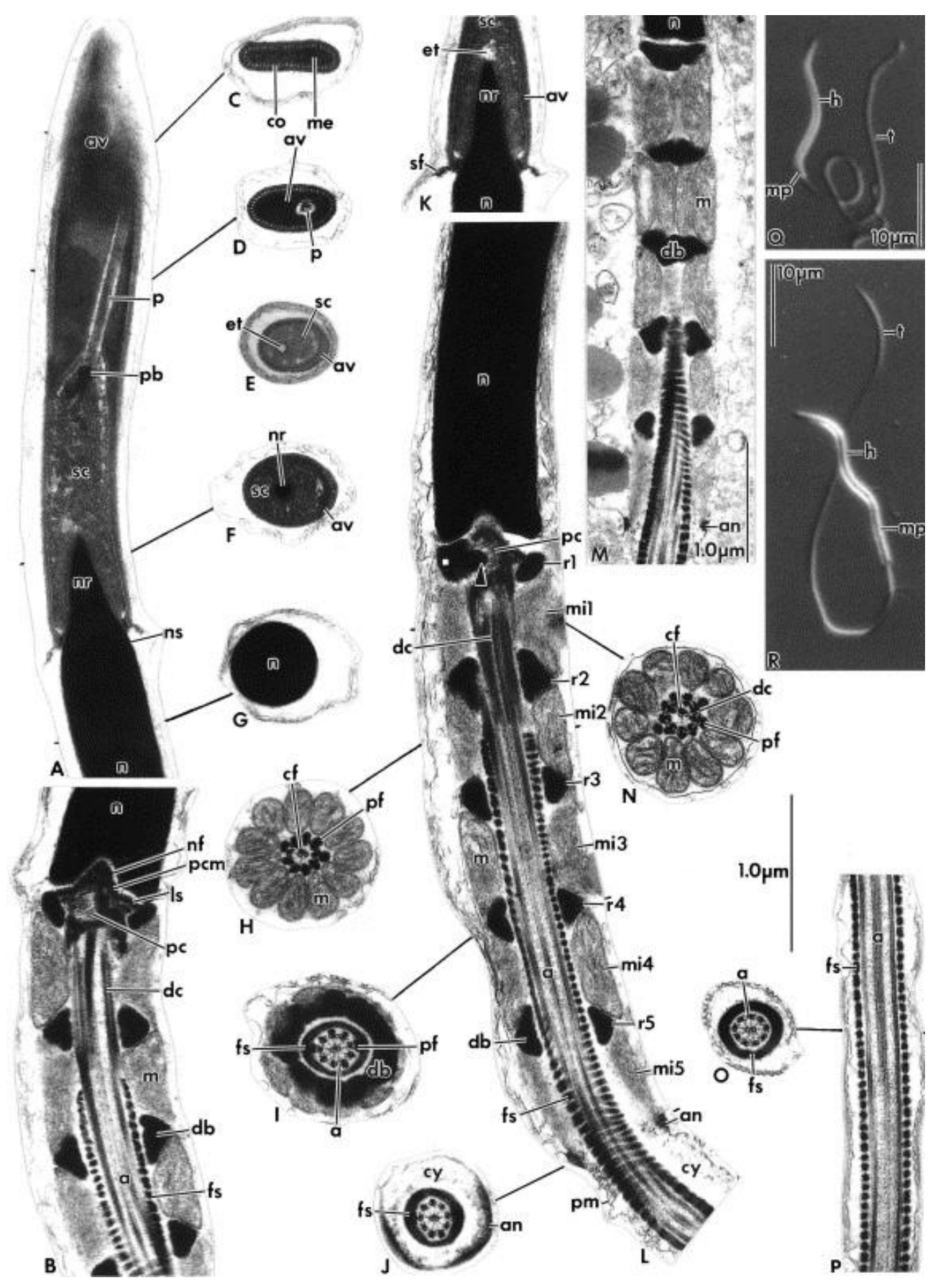

Fig. 2. Spermatozoa of Cnemidophorus gularis gularis $(A-D, F-L, \& N-P)$ and Cnemidophorus ocellifer ( $E$, $M)$. (A-P) Transmission electron micrographs. (A) Longitudinal section (LS) through the acrosome complex showing the acrosome vesicle with cortex and medulla, the subacrosomal cone, and perforatorium. Note the stopper-like perforatorium base plate. (B) LS of the anterior portion of the midpiece showing the neck region with the nuclear fossa, pericentriolar material, centrioles, and the stratified laminar structure. (C-J) A series of transverse sections (TSs) through the spermatozoon as indicated. Note that anteriorly, (C\&D), the acrosome appears depressed, while posteriorly, (E \& F), it is unilaterally ridged, $(G)$ through the nucleus, $(H)$ through posterior portion of the distal centriole, (I) through the complete dense body ring structure of the midpiece showing the peripheral fibers 3 and 8 thicker than the others, double and detached from their doublets, (J) through the annulus level. (K) LS of the nucleus rostrum. Note the epinuclear lucent zone at the nucleus tip. (L) LS of the full length of the midpiece showing five ring structures and mitochondrial tiers. Arrow indicates extension of dense body into center of the proximal centriole. (M) Oblique LS of the midpiece showing the mitochondrial and dense body arrangement. (N) TS through anterior portion of the distal centriole. (O) TS through the principal piece. (P) LS through the principal piece. ( $Q$ \& R) Light micrographs showing whole 
spermatozoon of (Q) C. ocellifer and (R) Kentropyx altamazonica. (A-P) Same scale as indicated. Abbreviations, a: axoneme; an: annulus; av: acrosome vesicle; cf: central fiber; co: cortex; cy: cytoplasm; $\mathrm{db}$ : dense bodies; dc: distal centriole; et: epinuclear lucent zone; fs: fibrous sheath; h: head; Is: stratified laminar structure; m: mitochondrion; me: medulla; mi: mitochondrial tier; mp: midpiece; n: nucleus; nf: nuclear fossa; nr: nuclear rostrum; ns: nuclear shoulder; $p$ : perforatorium; pb: perforatorial base plate; pc: proximal centriole; pcm: pericentriolar material; pf: peripheral fiber; pm:plasma membrane; rs: dense body ring structure; sc: subacrosomal cone; sf: flange of the subacrosomal material; t: tail.

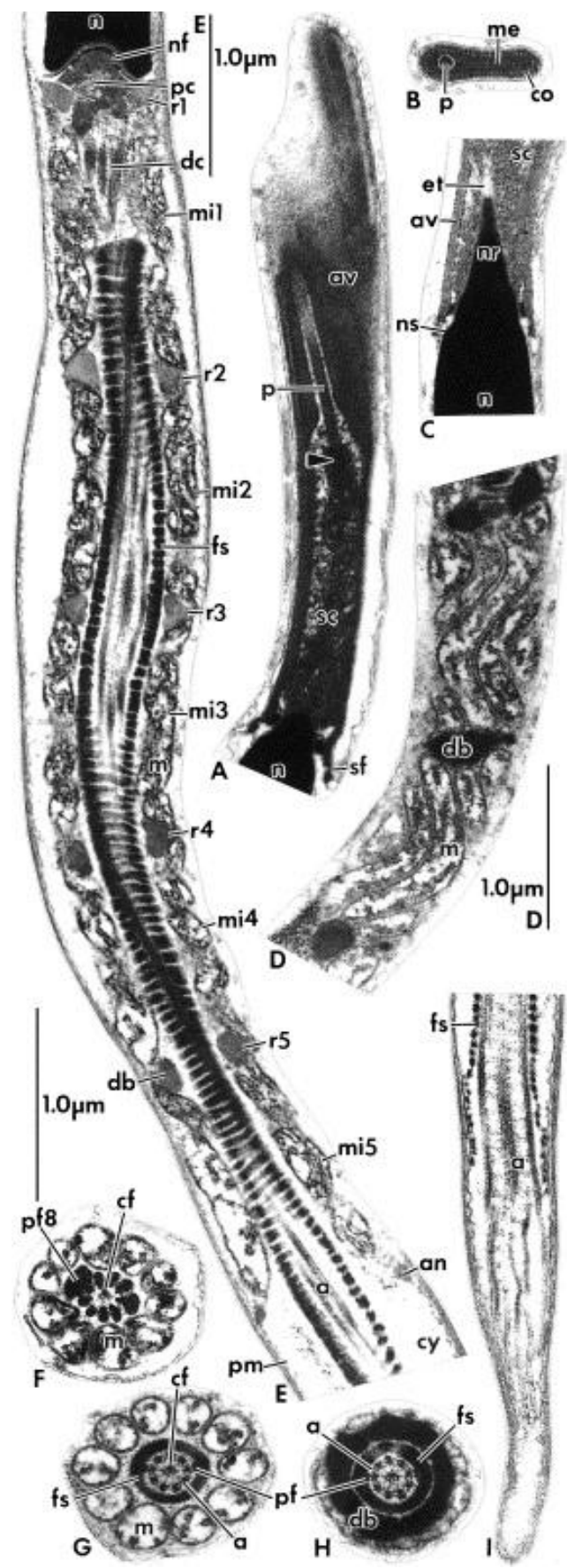

Fig. 3. Spermatozoa of Kentropyx altamazonica. (A-I) Transmission electron micrographs. (A) Longitudinal section (LS) through the acrosome showing the acrosome vesicle surrounding the subacrosomal cone and perforatorium. Arrow indicates a densification of the subacrosomal cone, may be a perforatorial base plate. (B) Transverse section (TS) through the anterior depressed portion of the acrosome. (C) LS through the nucleus rostrum. Note the epinuclear lucent zone at the nucleus tip. (D) Oblique LS of the midpiece, showing the mitochondrial and dense body arrangement. (E) LS through the entire length of the midpiece showing five dense body ring structures and mitochondrial tiers. (F) TS 
through posterior portion of the distal centriole showing that peripheral fibers 3 and 8 are grossly enlarged. (G) TS through the midpiece showing peripheral fibers 3 and 8 thicker than the others and detached from their doublets. $(\mathrm{H})$ TS through a complete dense body ring structure of the midpiece. (I) LS through the posterior portion of the principal piece and the endpiece. $(A-C)$ and $(F-I)$ Same scale as indicated. (D \& E) Scale as indicated. Abbreviations, a: axoneme; an: annulus; av: acrosome vesicle; cf: central fiber; co: cortex; cy: cytoplasm; db: dense body; dc: distal centriole; et: epinuclear lucent zone; fs: fibrous sheath; m: mitochondrion; me: medulla; mi: mitochondrial tier; n: nucleus; nf: nuclear fossa; nr: nuclear rostrum; ns: nuclear shoulder; p: perforatorium; pc: proximal centriole; pf: peripheral fiber; pf8: peripheral fiber at doublet 8; pm: plasma membrane; rs: dense body ring structure; sc: subacrosomal cone; sf: flange of subacrosomal material.

\section{Nucleus}

The nucleus is elongated and composed of highly condensed, electron-dense chromatin. In transverse section, the nucleus is circular throughout (Fig. 2F \& G). At its anterior extremity, the nucleus forms a point within the acrosome complex, the nuclear rostrum. The transition from the nuclear rostrum to the cylindrical portion of the nucleus is abrupt and marked by rounded nuclear shoulders (Fig. 2 and Fig. 3). Basally the nucleus terminates with a shallow concave depression, the nuclear fossa, which houses the anterior half of the proximal centriole and dense pericentriolar material (Fig. 2 and Fig. 3).

\section{Neck region}

The neck region lies at the junction between nucleus and midpiece. It contains the proximal and distal centrioles, the first ring of dense bodies, and mitochondria (Fig. 2 and Fig. 3). The proximal centriole is composed of nine short triplets and lies at approximately $80^{\circ}$ to the long axis of the spermatozoon (Fig. 2 and Fig. 3). A short, solid cylinder of electron-dense material extends from the first dense body ring structure into the center of the proximal centriole, for approximately half its length (Fig. 2L). The distal centriole constitutes the basal body of the axoneme. It is perpendicular to the proximal centriole, occupying a small fraction of the midpiece, and does not project into the fibrous sheath (Fig. 2B \& L). Dense pericentriolar material surrounds the proximal centriole and extends into the nuclear fossa. Posteriorly, it contacts the anterior portion of the distal centriole and provides a base for the nine peripheral dense fibers (Fig. 2B \& L). A poorly developed striated density, termed the stratified laminar structure, is continuous with the pericentriolar material and projects laterally from both sides of the anterior limit of the proximal centriole (Fig. 2B). 


\section{Midpiece}

The midpiece lies at the anterior portion of the flagellum. It includes the neck region and consists of the axoneme surrounded by mitochondria, rings of dense bodies, and the fibrous sheath (Fig. 2 and Fig. 3). The midpiece begins with the first ring of dense bodies and ends posteriorly at a small annulus (Fig. 2 and Fig. 3). The dense bodies occur as complete regular ring structures with a solid homogenous composition (Fig. 2 and Fig. 3). In transverse section, these ring structures appear juxtaposed to the fibrous sheath (Fig. 2 and Fig. 3). The dense bodies are separated longitudinally by one tier of columnar mitochondria. In K. altamazonica, the average distance between the ring structures is $1.29 \mu \mathrm{m}$, while in the two species of Cnemidophorus the distance is $0.44-0.45 \mu \mathrm{m}$. The ring structure and mitochondria arrangement pattern can be represented by the expression $\mathrm{rs} 1 / \mathrm{mi} 1, \mathrm{rs} 2 / \mathrm{mi} 2, \mathrm{rs} 3 / \mathrm{mi} 3, \mathrm{rs} 4 / \mathrm{mi} 4$, rs5/mi5, ( Fig. 2 and Fig. 3). In both species of Cnemidophorus, the mitochondria, when viewed in oblique section ( Fig. 2M), extend anterioposteriorly along the midpiece in a strictly columnar appearance, while in longitudinal section they appear trapezoidal ( Fig. 2B \& L). In K. altamazonica, the columnar mitochondria have a regular, slightly curved appearance in oblique section ( Fig. 3D). These mitochondria are not considered to be short sinuous tubes because they do not curve at an angle of greater than $45^{\circ}$ and back upon themselves. In $\mathrm{K}$. altamazonica, the ends of the mitochondria have a rounded shape as observed in longitudinal section ( Fig. 3E).

The axial component of the midpiece is the axoneme, which is composed of a pair of central microtubules (singlets) surrounded by nine doublets of microtubules. The singlets of the axoneme extend anteriorly throughout the length of the distal centriole (Fig. 2 and Fig. 3). Associated with the two singlets is a central fiber which is anteriorly located closer to triplet 9; posteriorly it decreases in size and is positioned centrally between the singlets of the axoneme (Fig. 2 and Fig. 3). The central fiber is vestigial at the level of the annulus (Fig. 2J).

A peripheral dense fiber is associated with each of the nine triplets of the distal centriole (Fig. 2 and Fig. 3). For a short distance, at the level of the distal centriole/axoneme junction, the peripheral fibers adjacent to doublets 3 and 8 appear grossly enlarged in $\mathrm{K}$. altamazonica ( Fig. 3F), whereas in Cnemidophorus the peripheral fibers associated with the distal centriole are all of a similar size. In all species, the nine peripheral fibers rapidly decrease in diameter posteriorly along the axoneme, with the exception of the fibers at doublets 3 and 8, which are thicker and form double fiber structures which are separated from their corresponding doublets and become closely associated with the fibrous sheath. At the level of the annulus, all nine dense fibers are vestigial or absent ( Fig. 2J). 
The fibrous sheath encloses the axoneme and extends into the midpiece, reaching the base of the distal centriole (Fig. 2 and Fig. 3). In both species of Cnemidophorus, the fibrous sheath extends anteriorly into the midpiece to the level of mitochondrial tier 2 (mi2) ( Fig. 2B \& L), occupying $68-69 \%$ of the total midpiece length. In K. altamazonica, the fibrous sheath extends to the level of the first mitochondrial tier (mi1) ( Fig. 3E), occupying $87 \%$ of the total midpiece length.

The annulus (Fig. 2 and Fig. 3) is a small dense ring with an irregular triangular shape in longitudinal section. It is closely attached to the inner surface of the plasma membrane and marks the end of the midpiece.

\section{Principal piece}

The principal piece is the longest part of the spermatozoon and occurs behind the midpiece. It consists of the axoneme surrounded by fibrous sheath, cytoplasm, and plasma membrane. In this region, all dense fibers, dense bodies, and mitochondria are absent (Fig. 20 $\&$ P). In the anterior portion of the principal piece, immediately after the annulus, the diameter of the spermatozoon does not decrease relative to the annulus diameter and the plasma membrane is widely separated from the fibrous sheath by a thick region of granular cytoplasm (Fig. 2 and Fig. 3; Table 1). Posteriorly, the plasma membrane becomes closely attached to the fibrous sheath (Fig. 2P).

\section{Endpiece}

A short length of axoneme extends beyond the posterior limit of the fibrous sheath as the endpiece (Fig. 3I). Posteriorly within the endpiece, the arrangement of microtubules becomes disrupted (Fig. 3I).

\section{Comparisons of spermatozoal dimensions}

All three species differed significantly in the dimensions of head, acrosome, distal centriole lengths, and nuclear shoulder width (Table 1). Lengths of the tail, entire sperm, midpiece, and nuclear rostrum were significantly different between K. altamazonica and C. gularis gularis, and between K. altamazonica and C. ocellifer, but not between the two species of Cnemidophorus. There was no statistical difference between any of the three species in 
nuclear base width, epinuclear lucent zone width or length, ratio of the diameter of the anterior principal piece to midpiece diameter, or the amount of cytoplasm within the anterior region of the principal piece (ratio of diameter of fibrous sheath to principal piece diameter) ( Table 1).

\section{Discussion}

The spermatozoa C. gularis gularis, C. ocellifer, and K. altamazonica exhibit the following squamate synapomorphies: a single wholly prenuclear perforatorium, endonuclear canal absent, paracrystalline subacrosomal material, mitochondrial cristae linear, intermitochondrial dense bodies present, and fibrous sheath extending into midpiece ( Jamieson \& Healy, 1992).

The three species of teiids studied share several characteristics in sperm ultrastructure: apical portion of acrosome depressed; acrosome vesicle divided into medulla and cortex; cortex with tubular organization; anterior portion of perforatorium positioned outside central one third of the flattened acrosome; epinuclear lucent zone short and thin; nuclear rostrum short; nucleus narrow basally; stratified laminar structure bilateral, poorly developed; central dense body within proximal centriole; distal centriole moderately long; midpiece short; mitochondria columnar; dense bodies solid, in regular and complete rings, juxtaposed to the fibrous sheath; ring structures of dense bodies separated by mitochondrial tiers; and thick zone of cytoplasm between plasma membrane and fibrous sheath in the anterior portion of principal piece.

Based on morphological data sets, Vanzolini and Valencia (1965) and Presch (1970) have suggested the presence of two groups within the family. One group is comprised of the genera Callopistes, Crocodilurus, Tupinambis, and Dracaena (subfamily Tupinambinae) and the other is comprised of Cnemidophorus, Ameiva, Teius, Kentropyx, and Dicrodon (subfamily Teiinae). This division is corroborated by one spermatozoal trait, the number of dense body ring structures, and mitochondrial tiers in the midpiece. In Cnemidophorus, A. ameiva ( Giugliano et al., 2002), and K. altamazonica, the midpiece has five sets of mitochondria intercalated with five sets of dense bodies, while in Tupinambis, Tavares-Bastos et al. (2002) observed six sets in T. quadrilineatus and T. teguixin, seven sets in T. duseni, and eight sets in T. merianae. However, despite members of Teiinae sharing more morphological characters with each other than with members of Tupinambinae (Presch, 1970), Cnemidophorus and A. ameiva share more sperm characters with Tupinambis than with K. altamazonica. The mitochondria of K. altamazonica are round ended while those of Cnemidophorus, A. ameiva ( 
Giugliano et al., 2002), and Tupinambis ( Tavares-Bastos et al., 2002) appear trapezoidal in longitudinal section. In K. altamazonica, the fibrous sheath occupies $87 \%$ of the entire midpiece, the highest proportion among all teiids studied. In A. ameiva ( Giugliano et al., 2002 ), the fibrous sheath occupies $75 \%$ of midpiece, in Cnemidophorus $68-69 \%$, and in Tupinambis ( Tavares-Bastos et al., 2002) it occupies 61-63\%. The average distance between ring structures of the midpiece is $1.29 \mu \mathrm{m}$ in $\mathrm{K}$. altamazonica, $0.75 \mu \mathrm{m}$ in A. ameiva ( Giugliano et al., 2002), $0.45 \mu \mathrm{m}$ in Cnemidophorus, and $0.27 \mu \mathrm{m}$ in Tupinambis spp. ( Tavares-Bastos et al., 2002), being two, three, and five times longer in K. altamazonica than in the other teiid genera, respectively. The mitochondria in K. altamazonica are longer and slightly curved, while in all other teiids studied, the mitochondria are straight and strictly columnar. These differences suggest that, among all these species examined, $\mathrm{K}$. altamazonica sperm may be the most derived. Comparisons of the sperm of Cnemidophorus spp. and K. altamazonica with that of previously examined teiids ultrastructure sperm indicate that the tubular organization observed in the cortex of the acrosomal vesicle is also present in A. ameiva (Giugliano et al., 2002) and Tupinambis spp. ( Tavares-Bastos et al., 2002). This feature seems to be an autapomorphy of the teiid lizards, however, more research on the other teiid genera sperm structure is needed to ascertain this character.

Cnemidophorus is regarded as the sister taxon of Ameiva ( Vanzolini \& Valencia, 1965). The only morphological character that distinguishes Cnemidophorus from Ameiva is the presence of a tongue sheath in Ameiva ( Presch, 1971). From sperm ultrastructure data, there are three characters that differ between the two genera: the absence of grossly enlarged fibers 3 and 8 at the distal centriole/axoneme junction in Cnemidophorus (present in A. ameiva), a slightly decreasing principal piece diameter immediately after annulus in A. ameiva (no decrease in Cnemidophorus); and the beginning of the fibrous sheath at mi2 in Cnemidophorus and at mi1 in A. ameiva (Giugliano et al., 2002).

The two Teiinae species previously studied, C. sexlineatus ( Newton \& Trauth, 1992) and A. ameiva ( Giugliano et al., 2002), show the same sperm characters as those species described here. According to Presch (1970), Kentropyx is closer to Ameiva and Cnemidophorus than to other Teiinae genera (Teius and Dicrodon). The unique character that distinguishes Kentropyx from Ameiva and Cnemidophorus is the shape of the parietal-frontal roof ( Presch, 1974). Spermatozoal ultrastructure distinguishes K. altamazonica from A. ameiva ( Giugliano et al., 2002) and Cnemidophorus in two features: the absence of a real perforatorial base plate and the presence of mitochondria with rounded ends instead of a trapezoidal shape in longitudinal section in the former. The sperm of K. altamazonica and A. ameiva ( Giugliano et al., 2002) are similar to each other and differ from those of Cnemidophorus in having 
peripheral fibers 3 and 8 grossly enlarged at the level of the distal centriole/axoneme junction and the fibrous sheath beginning at the level of mi1. In contrast to A. ameiva ( Giugliano et al., 2002), the principal piece of K. altamazonica sperm does not decrease in diameter immediately after the annulus. These results thus reveal that among the three genera of Teiinae studied, Ameiva shares two unique features with Cnemidophorus and Kentropyx, respectively, while Kentropyx and Cnemidophorus share only one unique feature, suggesting that Ameiva and Cnemidophorus may be more similar to each other than either is to Kentropyx [Kentropyx+(Ameiva+Cnemidophorus)].

This study has revealed that Cnemidophorus and Kentropyx sperm differ in three ultrastructural characters: presence of base plate, gross enlargement of peripheral fibers, and in the shape of the mitochondria. Furthermore, statistical analyses of the dimensions of 13 sperm characters found that four were significantly different between Cnemidophorus and Kentropyx, distinguishing these two genera. These results suggest high levels of intrafamily polymorphism in sperm ultrastructure within Teiidae. Conversely, the intrageneric variability appears to be relatively low, with sperm morphology of the congeneric C. gularis gularis and C. ocellifer being practically identical. They differ only in the dimensions of four sperm characters, i.e. head, acrosome, distal centriole lengths, and nuclear shoulder width. Additional work describing spermatozoal ultrastructure and statistical analyses of sperm dimensions of the teiid genera Callopistes, Crocodilurus, Dicrodon, Dracaena, and Teius are warranted to determine the real degree of variability in sperm ultrastructure between teiid genera and may cast light on the phylogenetic relationships of teiids.

\section{Acknowledgements}

We thank Adrian A. Garda, Daniel Diniz, and Renato G. Faria for assistance during fieldwork, and Daniel O. Mesquita and Gustavo H.C. Vieira for assistance with statistical analyses. Barrie G.M. Jamieson provided insightful comments on an earlier version of the manuscript. This work was supported by the School of Life Sciences and Department of Zoology and Entomology at the University of Queensland, CAPES, and CNPq.

\section{REFERENCES}

Avila-Pires, T.C.S. 1995. Lizards of Brazilian Amazonia. Nationaal Natuurhistorisch Museum, Alblasserdam, pp 514-516.

Colli, G.R., Péres Jr., A.K. and da Cunha, H.J. 1998. A new species of Tupinambis (Sauria, Teiidae) from central Brazil, with an analysis of morphological and genetic variation in the genus. Herpetologica, 54, 477-492. 
Degenhardt, W.G., Painter, C.W. and Price, A.H. 1996. Amphibians and Reptiles of New Mexico. University New Mexico Press, Albuquerque, p 431.

Gallagher Jr., D.S., Dixon, J.R. and Schmidly, D.J. 1986. Geographic variation in the Kentropyx calcarata species group (Sauria: Teiidae): a possible example of morphological character displacement. J. Herpetol., 20, 179-189.

Giugliano, L.G., Teixeira, R.D., Colli, G.R. and Báo, S.N. 2002. The ultrastructure of spermatozoa of the lizard Ameiva ameiva (Squamata, Teiidae). J. Morphol., 252, in press.

Jamieson, B.G.M. 1995. The ultrastructure of spermatozoa of the Squamata (Reptilia) with phylogenetic considerations. In: Jamieson, B.G.M., Ausio, J. and Justine J. (eds) Advances in Spermatozoal Phylogeny and Taxonomy. Muséum National d'Histoire Naturelle Paris, France, pp 359-383.

Jamieson, B.G.M. 1999. Spermatozoal phylogeny of the vertebrata. In: Gagnon, C. (ed) The Male Gamete: From Basic Science to Clinical Applications. Cache River Press, Vienna, Illinois, pp 303-331.

Jamieson, B.G.M. and Healy, J.M. 1992. The phylogenetic position of the tuatara Sphenodon (Sphenodontidae, Amniota), as indicated by cladistic analysis of the ultrastructure of spermatozoa. Phil. Trans. R. Soc. Lond. Biol. B: Biol. Sci., 335, 207-219.

Magnusson, W.E. and Lima, A.P. 1984. Perennial communal nesting by Kentropyx calcaratus. J. Herpetol., 18, 73-75.

Newton, W.D. and Trauth, S.E. 1992. Ultrastructure of the spermatozoon of the lizard Cnemidophorus sexlineatus (Sauria: Teiidae). Herpetologica, 48, 330-343.

Peters, J.A. and Orejas-Miranda, B. 1986. Catalogue of the Neotropical Squamata. Part II, Lizards and Amphisbaenians. Smithsonian Institution Press, Washington, D.C., p 293.

Presch Jr., W.R. 1970. The evolution of macroteiid lizards: an osteological interpretation. Ph.D. Thesis, University of Southern California, Los Angeles, CA.

Presch Jr., W.R. 1971. Tongue structure of the teiid lizard genera Ameiva and Cnemidophorus with a realocation of Ameiva vanzoi. J. Herpetol., 5, 183-185.

Presch Jr., W.F. 1974. Evolutionary relationships and biogeography of the macroteiid lizards (Family Teiidae, Subfamily Teiinae). Bull. Soc. Calif. Acad. Sci., 73, 23-32.

Rieppel, O. 1980. The trigeminal jaw adductor musculature of Tupinambis, with comments on the phylogenetic relationships of the Teiidae (Reptilia, Lacertilia). Zool. J. Linn. Soc., 69, 1-29.

Rocha, C.F.D., Araujo, A.F.B., Vrcibradic, D. and Costa, E.M.M. 2000. New Cnemidophorus (Squamata Teiidae) from coastal Rio de Janeiro state, southeastern Brazil. Copeia, 2000, 501509.

Rocha, C.F.D., Bergallo, H.G. and Peccinini-Seale, D. 1997. Evidence of an unisexual population of the Brazilian whiptail lizard genus Cnemidophorus (Teiidae), with description of a new species. Herpetologica, 53, 374-382. 
Tavares-Bastos, L., Teixeira, R.D., Colli, G.R. and Báo, S.N. 2002. Polymorphism in the sperm ultrastructure among four species of lizards in the genus Tupinambis (Squamata: Teiidae). Acta Zool. (Stockholm), 83, in press.

Teixeira, R.D., Colli, G.R. and Báo, S.N. 1999a. The ultrastructure of the spermatozoa of the lizard Micrablepharus maximiliani (Squamata, Gymnophthalmidae), with considerations on the use of sperm ultrastructure characters in phylogenetic reconstruction. Acta Zool. (Stockholm), $80,47-59$.

Teixeira, R.D., Colli, G.R. and Báo, S.N. 1999b. The ultrastructure of the spermatozoa of the worm-lizard Amphisbaena alba (Squamata, Amphisbaenidae), and the phylogenetic relationships of amphisbaenians. Can. J. Zool., 77, 1254-1264.

Vanzolini, P.E. and Valencia, J. 1965. The genus Dracaena, with a brief consideration of macroteiid relationships (Sauria, Teiidae). Arq. Zool., 13, 7-46.

Vanzolini, P.E., Ramos-Costa, A.M.M. and Vitt, L.J. 1980. Répteis das Caatingas. Academia Brasileira de Ciencias, Rio de Janeiro, Brasil, p 161.

Wiens, J.J. 1995. Polymorphic characters in phylogenetic systematics. Syst. Biol., 44, 482-500.

Wright, J.W. 1993. Evolution of the lizards of the genus Cnemidophorus. In: Wright, J.W. and Vitt, L.J. (eds) Biology of Whiptail Lizards (Genus Cnemidophorus). The Oklahoma Museum of Natural History, Norman, OK, pp 27-81.

Zar, J.H. 1998. Biostatistical Analysis. Prentice-Hall, Inc., Englewood Cliffs, NJ, p 663. 